Александар Хорват

Универзитет у Новом Саду

Филозофски факултет

Докторанд

aleksandarhorvat1987@yahoo.com
Оригиналан научни рад

примљено: 14. април 2014

прихваћено: 1. октобар 2014

\title{
ПОЛИТИЧКИ ЛЕГИТИМИТЕТ, МИТ, ВЕРНОСТ: ХАБЗБУРГОВЦИ У БУЊЕВАЧКОЈ И ШОКАЧКОЈ ЛИТЕРАТУРИ И ШТАМПИ 1790-1918.
}

Сажетак: Модернизацијске промене и изградња нација у Европи током XIX века утицале су на структурне промене у Хабзбуршкој монархији. Услед тих промена, династија Хабзбург је била присиљена да формира властити национализам како би задржала власт, комбинацијом старих средњовековних митова, облика верности и сакралности са идејама нових грађанских идеологија: либерализма и национализма. У раду ће бити анализирано на који начин су идеологије национализма и либерализма утицале на трансформације представа о политичком легитимитету власти династије Хабзбург у буњевачкој и шокачкој литератури и штапми. Уз то, разматраћемо облике митологизације Хабзбурговаца, али и идеју „верности династији“ као претпоставку формулисања и реализовања политичког програма буњевачкошокачког националног покрета. Анализом облика и трансформација политичког легитимитета, митова и верности покушаћемо утврдити на којим темељима је формиран колективни идентитет Буњеваца и Шокаца у јужној Угарској уочи пропасти Аустроугарске монархије и настанка југословенске државе.

Кључне речи: Буњевци, Шокци, династија Хабзбург, јужна Угарска, политички легитимитет, мит, верност, национални покрети, колективни идентитет.

Јужнословенске католичке етничке заједнице у јужној Угарској су од свог масовнијег насељавања у Хабзбуршкој монархији крајем XVII века, посредно и непосредно дошле у додир са представницима династије Хабзбург. Учешће и заслуге у ратовима и биткама против Османлија награђивани су племством појединим буњевачким породицама. Комуникација и контакти су настављени у XVIII веку, посебно у време признавања Сомбора и Суботице за слободне краљевске градове. Тада су представници Буњеваца и Срба заједно путовали у Беч, како би остварили своје захтеве, до чега је у случају Сомбора дошло 1749, а Суботице 1779. године. ${ }^{1}$

\footnotetext{
${ }^{1}$ О томе више у: Иван Иванић, Буњевцุи и Шокции у Бачкој, Барањи и Лици, Београд 1899, 59-92; Petar Pekić, Povijest Hrvata u Vojvodini: od najstarijih vremena do 1929. godine, Zagreb 1930, 46-91; Алекса Ивић,
} 
Објављивање епа фрањевца Гргура Пешталића ${ }^{2}$ Достојна племените Бачке 1790. године, представља полазну тачку у разматрању и интерпретацији дефинисане теме. Овај спис омогућава увид у ставове и размишљања оновремених писмених људи. Пошто је аутор у епу описао одлазак буњевачког племства на крунисање цара Леополда II (1790-1792) у Пешту, то отвара следећа проблемска питања: какав је положај буњевачког племства унутар угарске „сталешке нације“, односно угарског племства? Да ли је могуће сазнати став према питању легитимитета политичке власти, односно да ли аутор износи размишљања о извору царевог положаја као суверена? Какав је уопштено однос аутора према династији Хабзбург?

Разматрање теме о Хабзбурговцима у буњевачкој и шокачкој литератури и штампи је вишеструко сложен проблем, па је у првом реду потребно врло прецизно контекстуализовати процесе и догађаје. Период од 1790. до 1918. у Европи обележавају процеси модернизације и изградње нација као модерних политичких творевина. Да би проблематизовали тему, а затим добили одговоре на проблемска питања везана за сложеност, структуру и функцију начина и облика тематизовања Хабзбурговаца у литератури и штампи, потребно је у основним линијама размотрити главне тезе о проблемима везаним за појаву националних покрета у Европи, ширење грађанских идеологија и промене које су последично захватиле простор Хабзбуршке царевине. Другим речима, потребно је дефинисати специфични облик национализма контролисаног од стране династије и Монархије, као реакције на развој етничких и језичких националних покрета у XIX веку. Средишње место у разматрању припада питању политичког легитимитета, као извора на којем се заснива власт у свакој држави.

У исто време када је Пешталић писао свој еп, у Европи је Француском револуцијом отворена нова епоха - доба нација и национализама. ${ }^{4}$ Као резултат процеса економске, друштвене и политичке модернизације, европски континент је у наредним деценијама обележила изградња нација, као новог средства легитимитета модерног политичког поретка. ${ }^{5}$ Национализми, нације и идеја националног

\footnotetext{
Из прошлости Буњеваца, О Буњевцима (зборник радова, ур. Милоје В. Кнежевић), Суботица 1927, 12-17; Јован Радонић, О сеоби Буњеваца у Суботииу 1687. године, сепарат, Београд 1954, 119-127; Славко Гавриловић, Сомбор у борби за елибертацију: 1745-1749, Зборник Матице српске за историју, 37, Нови Сад 1988, 43-79.

${ }^{2}$ Гргур Пешталић (1755-1809) рођен је у Башкуту недалеко од града Баје. Завршио је студије филозофије и теологије вероватно у Будиму. Обављао је службу професора у бројним фрањевачким школама, од Баје до Мохача и Вуковара. Осим познатог епа Достојна племените Бачке, написао је низ филозофских дела на латинском. Умро је у Баји. (Nevenka Bašić-Palković, Grgur Peštalić: dostojna plemenite Bačke starih uspomena (1790), prvi rodoljubivi ep u književnosti bačkih Bunjevaca XVIII veka i njegova izdanja, Etnolingvistička i istorijska istraživanja o Bunjevcima (zbornik radova, ur. Mato Pižurica, Suzana KujundžićOstojić), Novi Sad - Subotica 2008, 49-59; Marko Čović, Aleksandar Kokić, Bunjevci i Šokci, Zagreb 1939).

${ }^{3}$ Grgur Peštalić, Dostojna plemenite Bacske starih uspomena sadashnji i drugi slavinske kervi delliah slava, Subotica 1866.

${ }^{4}$ О теорији национализма вид. више у: Ернест Гелнер, Нације и национализам, Нови Сад 1997; Erik Hobsbaum, Nacije i nacionalizam od 1780: program, mit, stvarnost, Beograd 1996; Antoni D. Smit, Nacionalni identitet, Beograd 1998; Anthony D. Smith, Nacionalizam i modernizam: kritički pregled suvremenih teorija nacija і nacionalizma, Zagreb 2003; Ханс-Улрих Велер, Национализам: историја, форме, последице, Нови Сад 2002.

${ }^{5}$ Tihomir Cipek, Nacija kao izvor političkog legitimiteta, Nacija i nacionalizam u hrvatskoj povijesnoj tradiciji
} 
суверенитета, односно власти која произлази из воље „народа“, обликују се као супротност дотадашњој идеологији и власти владара темељеној на божијој милости, феудалном поретку и подаништву већине становништва. Монархистички принципи мишљења, владања и система вредности су постепено почели уступати место грађанским идеологијама, национализму и либерализму. Нација је у очима идеолога национализма представљала заједницу припадника са једнаким грађанским и политичким правима, из чије воље и националног интереса је проистицао суверенитет и легитимитет сваке власти.

У појединим феудалним монархијама, као реакција на национализам и националне покрете XIX века, настао је специфичан облик политичког легитимитета и државног национализма, који Ситон-Вотсон назива „службеним национализмом“.6 Тиме је замењен монархистички легитимизам који је почивао искључиво на средњовековним митовима, сакралности и пукој древности династија и владара. Како примећује Бенедикт Андерсон, то је био покушај „да се растегне уска, тесна кожа нације око оријашког тела империје“. Конкретна делатност „службеног национализма“ састојала се од државне пропаганде, утицаја у образовању, „службеног“ мењања прошлости, па чак и манипулација са стварношћу, и безбројним понављањем тврдњи о истоветности династије и нације. ${ }^{7}$

У случају Хабзбуршке монархије, већ је цар Франц I (II) (1792-1835) уочавао недостатке старог традиционалног поретка у царевини, иако је суштински био противник принципа револуције: демократије, либерализма и национализма, као „сила нереда“. Криза монархистичког легитимитета нужно је усмеравала првог аустријског цара и целу Монархију у новим правцима. Цео процес је био условљен потребом да се трансформише стари систем који је био угрожен. Уочено је да се идеја о „вољи народа“ мора прилагодити монархијском принципу, како би царевина опстала. Стога, цар је себе представљао као лидера и оца својих народа. Финансирао је нови монархијски култ, који је темељен управо на квалитетима лидерства и очинства, уско повезаним са отвореношћу према представницима „народа“. У ту сврху, цар је два пута недељно примао грађане и разне делегације, разговарао с њима на њиховим језицима и решавао проблеме. Брисање старих традиција је постало нарочито видљиво када се Франц прогласио за аустријског цара 1804. Пошто је Свето римско царство престало да постоји тек 1806, овај владар је две године био цар две царевине. Нови облик легитимизације темељио се на увођењу снаге јавног мњења као нове друштвене религије. Цар је финансирао поновно писање историје, којем је основна сврха било конструисање аустријског националног идентитета базираног на историји династије Хабзбург. Династија је добила нови смисао и значење у будућности, приказивањем „срећне прошлости Хабзбурга“. Настајала су и уметничка дела која су приказивала представнике династије, славећи њену прошлост и предстојећу улогу у будућности „народа“. Цар је на многим сликама приказан као човек из народа, којег људи воле, али и он

(zbornik radova, ur. Tihomir Cipek, Josip Vrandešić), Zagreb 2007, 17-31.

${ }^{6}$ Hugh Seton-Watson, Nacije i države: ispitivanje porijekla nacija i politike nacionalizama, Zagreb 1980.

${ }^{7}$ Benedikt Anderson, Nacija:zamišljena zajednica, Beograd 1998, 81-104. 
показује бригу за њих. Стваран је утисак одређене везе између цара и народа, која није била темељена искључиво на подаништву, него на међусобној љубави и поштовању. Царев портрет је бивао све раширенији у кућама обичних људи као израз лојалности и патриотизма. ${ }^{8}$

Међутим, овај делимично модификовани поредак нашао се пред великим искушењима у време револуције 1848-49. Идеја о грађанским правима стигла је у царство и угрозила опстанак династије и државе. ${ }^{9}$ Пошто је Монархија ипак „преживела“ револуцију, утицај револуционарних догађаја и ерупција идеја „сила нереда“ условили су нове трансформације „службеног национализма“ у другој половини XIX века. Цар Франц Јозеф (1848-1916) деловао је на изградњи новог култа династије и монарха као „првог слуге“ својих народа, слично као његови претходници из XVIII века - Јозеф II (1780-1790) и Леополд II (1790-1792). Међутим, његова одбојност према либерализму и сваком облику уставне владавине била је условљена његовим конзервативним образовањем. Уступци које је чинио демократским и националним струјањима били су више део напора да се очува јединство Монархије, а не политичко или идеолошко убеђење. Разне прославе и манифестације организоване су како би се повезале потреба за стварањем лојалности династији, „величанствена прошлост“ и веза монарха са „народима“ Монархије. Прослава 60 година владавине Франца Јозефа 1908. садржавала је највише националних елемената. Свака покрајина царства послала је представнике који су учествовали у великој поворци, како би се манифестовала идеја о заједничким интересима, историји и судбини династије и „њених народа““. ${ }^{10}$ Ипак, као и остали Хабзбурзи, Франц Јозеф суштински никада није напустио уверење о божанском праву своје владавине као старом мистичном наслеђу династије. То убеђење је засигурно представљало основну препреку у изградњи новог типа политичког легитимитета, који би заиста произлазио искључиво или претежно из воље „народа“. Због очувања старих верских концепција и средњовековног мистицизма, суштински, „службени национализам“ династије није успео заузети доминантну позицију у Монархији. ${ }^{11}$ Све пресуднију улогу су добијали национални покрети појединих етничких заједница у царству, који су се нагло развијали у другој половини XIX века.

Пошто проблем легитимитета политичке власти и митови на којима се он изграђује очито има важну улогу у политичкој модернизацији, трансформацији етнија у нацију и изградњи националног идентитета, у првом реду ћемо анализирати на који начин је то питање схватано и тумачено у оновременој буњевачкој и шокачкој штампи, а затим довођено у везу са династијом Хабзбург. Друго проблемско питање ће се односити на облике митологизације династије као важне полуге у одржавању власти сваког „службеног национализма“. У фокусу ће бити садржај нових-старих митова делимично прилагођених грађанским идеологијама.

\footnotetext{
${ }^{8}$ Andrew Wheatcroft, The Habsburgs, London 1995, 236-255.

9 Ален Џ. П. Тејлор, Хабзбуршка монархија: историја Аустријске ичаревине и Аустроугарске, Београд 2001, 63.

${ }^{10}$ Више у: Жан-Пол Блед, Франц Јозеф, Београд 1998; A. Wheatcroft, The Habsburgs, 267-284.

${ }^{11}$ B. Anderson, Nacija, 100-109.
} 
Трећи проблем ће обухватати практичну примену идеолошке концепције „верности династији и домовини“ током буњевачке и шокачке прошлости, у изградњи политичког програма националног покрета.

Анализа трансформација политичког легитимитета у јужнословенским католичким етничким заједницама јужне Угарске и улога династије Хабзбург у том процесу, враћа нас на проблем постављен на почетку рада. Како је већ речено, питања се односе на суштински значај Пешталићевог епа и интерпретацију ауторових идеолошких ставова везаних за концепцију легитимитета и извора власти цара и династије.

Када је реч о положају буњевачког племства унутар угарске „сталешке нације“ и односу према династији и цару, Пешталић у свом епу често наглашава да су племићи водили и водиће битке у име домовине, краља-цара и Бога. Са поштовањем и бројним епитетима наводи све цареве за које су се верно борили, као „чувари домовине“. Пошто се цар Јозеф II није окрунио за угарског краља, а круну Св. Стефана је однео у Беч, аутор повратак круне и Леополдово крунисање објашњава као „небеску пригоду“, односно повратак старом и природном стању. Осим тога, круни као предмету приписује елементе светости, па чак износи тезу да из саме круне произлази слобода. ${ }^{12}$ Дакле, према Пешталићу, политички легитимитет хабзбуршких царева у Угарској уско је везан за њихово крунисање круном Св. Стефана. Његове тезе су сасвим у складу са идејама угарског племства и сталешким конституционализмом угарске „сталешке нације“ формулисаним у отпору реформним настојањима цара Јозефа II. Племићки сталеж био је уједињен у надетничку групу „Natio Hungarica““13. Међутим, независно од тога, у епу се могу приметити извесни протонационални елементи у словенском духу. Пешталић није дефинисао сасвим јасно етничко порекло племства о којем говори, нити даје у том контексту специфичну одредницу у смислу етничке припадности, али ипак на неколико места их неодређено помиње као „Славине“. ${ }^{14}$ Пешталићев текст садржи и идеје о свесловенској узајамности, иначе својствене јужнословенским католичким писцима још од XVI века. ${ }^{15}$ Тек у време развоја буњевачко-шокачког националног покрета шездесетих година XIX века, овај еп добија многе друге конотације, које у времену кад је настао свакако није имао, нити је могао имати.

Идентификација буњевачког са угарским племством добила је пуну потврду у наредним годинама. У првој половини XIX века услед раста броја писменог становништва, „културне стандардизације“ и модернизације, развија се мађарска либерална интелигенција, која дефинише нове концепте националне интеграције, сасвим различите од идеја угарског племства. Међу тим концепцијама преовладава

\footnotetext{
${ }^{12}$ G. Peštalić, Dostojna plemenite Bačke, 26.

${ }^{13}$ Horst Haselsteiner, Problem narodnosti u zemljama ugarske krune, u: H. Haselsteiner, Ogledi o modernizaciji, Zagreb 1997, 329.

${ }^{14}$ G. Peštalić, Dostojna plemenite Bačke, 17, 35.

${ }^{15}$ О идеологији свесловенске узајамности код хрватских аутора Винка Прибојевића и Јурја Крижанића уп.: Ivo Banac, Nacionalno pitanje и Jugoslaviji: porijeklo, povijest, politika, Zagreb 1988, 76-78. Ова идеологија је постала посебно популарна током XVIII века и врло присутна у књижевним делима Андрије Качића Миошића, Матије Антуна Релковића и других јужнословенских писаца, па и Гргура Пешталића.
} 
идеја о јединственој угарској „политичкој нацији“. Ова идеја свој израз добија у асимилацији, стапању разних етничких заједница у састав угарске „политичке нације“. И угарско племство прихвата нове идеје, како би спречило властиту политичку маргинализацију. ${ }^{16}$ Интеграција прве буњевачке и шокачке елите у мађарску нацију потврђена је током Револуције 1848-49, када је велика већина племства и школованог становништва била на страни Мађара. Исти тренд је настављен и у наредним годинама, током постојања Српског Војводства (1849-1860). Мађаризовани Буњевци су захтевали укидање Војводства и припајање његових области Угарској, а када је царском одлуком оно укинуто 1860 , прослављали су тај догађај. ${ }^{17}$

Тек после Аустро-угарске нагодбе 1867. и доношења Закона о народностима 1868. у угарском делу Монархије, отпочео је развој буњевачког и шокачког националног покрета, ${ }^{18}$ утемељеног на југословенској идеологији. Уследила је релативно богата продукција разних публикација, поготово новина. ${ }^{19}$ Објављиване су књиге различите провенијенције, речници, уџбеници, поезија, календари и историјска литература. Основни напори покрета све до 1918. везани су за остваривање права дефинисаних Законом о народностима и Законом о основним школама, који су гарантовали грађанска права и употребу језика народности у настави. Међутим, пошто је Закон о народностима маргинализован, поготово од средине седамдесетих година XIX века, развој буњевачко-шокачког националног покрета није успео да спречи снажан процес мађаризације, односно асимилације и стапања с Мађарима, којем су Буњевци и Шокци били изложени. ${ }^{20}$

\footnotetext{
${ }^{16}$ B. Anderson, Nacija, 99-101; Nikša Stančić, Između političkog nacionalizma i etnonacionalizma: od hrvatske staleške „nacije“ (natio croatica) do hrvatskog ,političkog naroda“, Nacija i nacionalizam u hrvatskoj povijesnoj tradiciji (zbornik radova, ur. Tihomir Cipek, Josip Vrandešić), Zagreb 2007, 40-44; H. Haselsteiner, Mađarski nacionalni koncepti, Slaveni i „Austro-slavizam“, u:H. Haselsteiner, Ogledi o modernizaciji, Zagreb 1997, 391-411. Хаселштајнер је у наведеном раду дефинисао низ мађарских националних концепција, полазећи од федералистичких решења, све до идеја о консолидованој, органски сраслој нацији.

${ }^{17}$ Федор Никић, Румуни банатски и Буњевции према српској Војводини у год. 1848-1849, Летопис Матице српске, год. 101, књ. 313, св. 1-3, Нови Сад 1927, 406-415; Ф. Никић, Буюевци и Српска Војводина 1860 , О Буњевцима (зборник радова, ур. Милоје В. Кнежевић), Суботица 1927, 41-45.

18 Неколицина аутора је у својим радовима анализирала настанак и развој буњевачко-шокачког националног покрета у јужној Угарској до 1918, међутим ови радови су у потпуности аисторични, јер се темеље на органицистичком схватању нације и конструкцијама о хрватском националном идентитету код јужноугарских Буњеваца и Шокаца пре ХХ века. Неки од тих радова су: Славко Кузмановић, $O$ националном препороду буњевачких Хрвата, Зборник за историју, 20, Нови Сад 1979, 131-159; Ante Sekulić, O društvenom i stranačkom životu podunavskih Hrvata od 1867. do 1918, Historijski zbornik, sv. 41, br. 1, Zagreb 1988, 123-183; Robert Skenderović, Oblikovanje bunjevačkog političkog identiteta u Bačkoj tijekom druge polovice XIX stoljeća, Časopis za suvremenu povijest, sv. 44, br. 1, Zagreb 2012, 137-160; Robert Skenderović, Suradnja biskupa J. J. Strossmayera i Ivana Antunovića, Croatica Christiana periodica, 59, Zagreb 2007, 85-103; Slaven Bačić, Nacionalno-integracijski procesi Bunjevaca u Bačkoj i ugarskom Podunavlju, Godišnjak za znanstvena istraživanja Zavoda za kulturu vojvođanskih Hrvata, br. 2, Subotica 2010, 65-76.

${ }^{19}$ Прве су се појавиле Буњевачке и шокачке новине 1870, да би до 1918, дуже или краће време излазили следећи листови: Буњевачка и шокачка вила, Мисечна кроника, Субатички гласник, Невен, Буњеваи, Јужна Угарска, Суботичке новине, Напред и Наме новине. Први буњевачки календар изашао је 1868, а од 1884. излазио је годишњи календар Суботичка Даница.

20 Arnold Suppan, Cuius regio eius natio: nacionalno razgraničavanje, isključivanje $i$ asimilacija $u$ srednjoistočnoj Europi, u: A. Suppan: Oblikovanje nacije u građanskoj Hrvatskoj (1835-1918), Zagreb 1999, 30; Васа Стајић, Мађаризаџија и демађаризаџија Буњеваџа, Летопис Матице српске, год. 104, књ. 325, св.
} 
Радикално повећавање броја публикација и раст издаваштва омогућавају да се прецизније анализирају постављена проблемска питања: питање политичког легитимитета власти, митолошка представа о династији и улога концепције „верности династији и домовини“ у развоју буњевачко-шокачког националног покрета.

Питање политичког легитимитета власти династије и његово конструисање доживело је значајне промене током друге половине XIX века. Средњовековне и феудалне концепције власти, у случају Угарске углавном везане за круну Св. Стефана, и даље су остале присутне, међутим уз све јаснију артикулацију концепција темељених на грађанским идеологијама, снажно повезиваних са династијом Хабзбург.

Приликом обележавања 25 година од царевог крунисања круном Св. Стефана 1867, један буњевачки аутор је у Суботичкој Даници детаљно описао чин крунисања „свитлом и славном круном“. Сам догађај објашњава као враћање поверења између владара и угарских народа. Нагодба је тумачена као договор „краља и домовине“ и нека врста заштите и гаранције за народе, чији је коначни резултат устав. Ипак, у чину крунисања задржане су и старе традиције, карактеристичне за „службене национализме“ монархијских држава. Угарски примас, надбискуп острогонски, миропомазао је краља, али је цела церемонија допуњена грађанском симболиком, јер је угарски премијер, као световни лидер у Угарској, положио круну краљу-цару на главу. Упркос томе, новине и литература су и даље истицали „стародавност“ предмета, обичаја и свега осталог што се налазило у близини припадника династије и што је садржавало у себи одређени политички легитимитет, ако ништа друго, а оно због своје „стародавности“. Цар-краљ се у присуству „целог народа“ заклео да ће поштовати и бранити правду и угарски устав. Буњевачки аутор закључује како се „краљ венчао са народом“ и како је настао „нов устав и нов живот“. Међутим, овај писац је јасно дефинисао да династија није одредила свој однос само према „народу“, него и према круни. Према томе, права и дужности сваког грађанина била су везана и за устав и за круну Св. Стефана, која на тај начин задржава важну улогу у животу сваког појединца. Буњевачки аутор о томе пише: „Скупоцена је и драга народима као и Буњевцу који лојално и са почитањем

1-3, Нови Сад 1930, 158-209. Разматрање развоја и политичког карактера буњевачко-шокачког националног покрета, његове социјалне, економске и идеолошке основе, захтева посебну анализу. У теоријском погледу полазна тачка би требало да буде чувена студија Мирослава Хроха и његова подела развоја националних покрета на три фазе: литерарну фазу (период настанка разних научних и књижевних радова мотивисаних национализмом просветитељског типа), агитацијску фазу и фазу масовног покрета (Miroslav Hroch, Društveni preduvjeti nacionalnih preporoda u Europi - komparativna analiza društvenog sastava patriotskih grupa malih europskih nacija, Zagreb 2006). Касније је Хорст Хаселштајнер додао четврту фазу политичке консолидације, односно консолидације масовног покрета у једној држави и преузимање државне власти. Тиме је Хрохов модел допуњен, а аутор је указао на могућност прекида интеграцијских процеса, као и на то да се нације развијају, али и нестају или постају део других националних интеграција (Н. Haselsteiner, O ројти nacionalizma i njegovim strukturama u Jugoistočnoj Europi u 19. i početkom 20. stoljeća, u: H. Haselsteiner, Ogledi o modernizaciji, Zagreb 1997, 313-315). Хаселштајнерова допуна је посебно важна за анализу буњевачко-шокачког националног покрета, с обзиром на његов сложен историјски развој, нове смерове националне интеграције у Краљевини СХС/Југославији и последице које су видљиве и данас. 
воли говорити о светој круни краља““ ${ }^{21}$

Пошто је према тадашњој идеологији круна гарантовала сва права појединим народима, важност царевог крунисања истицана је годинама после Нагодбе, тумачена у штампи и календарима. Идеје подаништва и владарске супремације заузимале су и даље значајно место у буњевачкој и шокачкој литератури и штампи. У угарском делу Монархије био је на делу врло комплексан тип политичког легитимитета, одређен у троуглу династија-круна-устав (закони). Буњевачки аутори су износили тезе о пресудној улози цара у друштву, који је „глава над тилом“. Пошто је његова личност повезивана са светошћу, потребно је клањати се пред њим, ${ }^{22}$ како стоји у појединим новинским чланцима. У кризним моментима враћање средњовековној терминологији није била реткост, па су новине често обиловале тврдњама о божијој интервенцији и судбини династије да влада над народима Монархије. Престолонаследник Рудолф је описан као човек „од свевишњег Бога позван, и од судбе означен да влада толиким народима“. ${ }^{23}$

Паралелно са типом легитимитета који се заснива на „светој круни“, „божијој интервенцији“ и „судбини“, већ од 1870. и појављивања првих буњевачкошокачких новина, поједини аутори су разматрали питања везана за политички легитимитет власти, уставност, грађанску слободу и све друге појмове везане за грађанске идеологије. Иако је, како смо видели, круна Св. Стефана задржала све идеолошке конотације из ранијих времена, паралелно се појављује нова терминологија. Слобода се везује не само за круну, него и за уставност, па је формулисан термин „грађанске уставне слободе“. ${ }^{24}$ Новински чланци су образлагали све новости које доноси „ново време“, укључујући идеје управе и самоуправе које се тичу сваког грађанина. Појашњавано је да се закони и судске пресуде доносе у име краља, али да се тиме не ускраћује самоуправа, јер законе изгласава сабор биран од стране народа. Као носиоци власти су означени сабор, краљ и влада, чиме је у значајној мери измењен стари систем власти. Влада пре Нагодбе је називана самовољном, а да су после 1867. народи добили окруњеног краља „жељом цилог народа“. ${ }^{25}$ Тиме је политички легитимитет цареве-краљеве владавине директно повезан са „народном вољом“, односно националним суверенитетом. Политички легитимитет власти је добио нове изразе у формулацијама о „слободи која проистиче из закона и онемогућује самовољу било кога“. ${ }^{26}$ Пошто се та теза односи на све, претпостављамо да се односила и на цара. Буњевачки и шокачки листови су писали како владар у „новом времену“ управља и влада уз саветовање са народима, ${ }^{27}$ а пословима које су до тада обављали људи именовани од цара предају се људима изабраним од стране грађана и сада су они њима одговорни. ${ }^{28}$

Буњевачки и шокачки аутори су у духу грађанских идеологија уставно и

${ }^{21}$ Subotička Danica: kalendar za 1893. godinu, Subotica 1892, 20-29.

${ }^{22}$ Bunjevačke i šokačke novine, 26. ožujka 1870, 2.

${ }^{23}$ Subotička Danica: kalendar za 1893. godinu, Subotica 1892, 46-49.

${ }^{24}$ Bunjevačke $i$ šokačke novine, 19. ožujak 1870, 1.

${ }^{25}$ Subotička Danica: kalendar za 1893. godinu, Subotica 1892, 20-29.

${ }^{26}$ Bunjevačke i šokačke novine, 5. travnja 1870, 4.

${ }^{27}$ Neven, 15. rujna $1885,9$.

${ }^{28}$ Bunjevačke i šokačke novine, 26. ožujka 1870, 2. 
политичко право дефинисали као право једнако за сваку „народност“. Сходно томе, они су сва права захтевали на буњевачком језику. Охрабрен идејом о националном суверенитету као извору политичког легитимитета „Један Славенофил“ је 1870. отишао корак даље од осталих аутора и разматрао могућност пропасти Монархије због проблема везаних за права Словена и неиспуњење њихових захтева. ${ }^{29}$ Следеће године појављује се један чланак у Буњевачким и шокачким новинама у којем пише да свака народност мора добити права гарантована уставном слободом. У том чланку се поставља питање да ли је рука апсолутизма или рука уставна примила жезло управе. Затим следе тезе о незадовољству „народности“ уставним положајем и могуће последице „ограничења слободе“ да Буњевци и Шокци могу тражити помоћ „од туђина и од браће“. ${ }^{30}$ Нема сумње да је политички легитимитет у Монархији и његово тумачење у буњевачкој и шокачкој штампи и литератури задржао многе елементе карактеристичне за предреволуционарни период. Међутим, у његовој сложеној конструкцији појављује се теза о власти која се темељи на вољи „народа“ и коју „народ“ контролише. Управо та концепција је пресудна за грађење националног идентитета и нација као модерних творевина, јер без идеје о националном суверенитету она не постоји. Буњевачко-шокачки национални покрет је у том смислу остварење идеала слободе везивао за љубав према домовини, али и за остварење грађанских и политичких права сваког појединца као припадника одређене „народности“.

Митологизација Хабзбурговаца у буњевачко-шокачкој штампи имала је разноврсне облике. Основне митске конструкције темељене су на тезама о Хабзбурговцима као браниоцима хришћанства од турске опасности, ослободиоцима Угарске и приписивању цару Францу Јозефу демократских и либералних склоности. Стварност је улепшавана и делимично искривљена, у складу са интересима „службеног национализма“ династије.

Сасвим природно, цару Францу Јозефу је припадало централно место у конструисању митских представа о династији Хабзбург. Честа тема у буњевачкошокачкој штампи била је његова мудрост, захваљујући којој је измирио народе у царевини Аустро-угарском нагодбом 1867. ${ }^{31}$ Цео процес и догађаји везани за доношење Нагодбе поједностављено су приписани царевој личној одлуци. Истовремено, тиме је увођење уставног стања и новог законодавства представљено као израз цареве демократичности и склоности према „његовим народима“. Како се XIX век ближио крају, текстови у буњевачким и шокачким листовима све чешће су садржавали тезе о наводној царевој демократичности и либерализму, као и о вољи и жељи да уставно влада у договору са својим народима. Приликом царевог рођендана 1885 , суботички Невен је устврдио како „љубљени владар са својими народими добро и зло дили“ и како само уз њихово саветовање влада и управља. Осим тога, одавање почасти и поштовања владару допуњено је следећим речима: „Млади и стари, богати и убоги, сви се надмећу, да тога дана побожними молитвами и разним

\footnotetext{
${ }^{29}$ Bunjevačke i šokačke novine, 7. prosinca 1870, 39.

${ }^{30}$ Bunjevačke i šokačke novine, 23. studena 1871, 47.

${ }^{31}$ Bunjevačke $i$ šokačke novine, 30. ožujka 1870, 3.
} 
свечаностима прид цилим свитом покажу, да увик живи позната приврженост аустро-угарских народах наспрам цару и краљу и држави у свих срцих и да неима у свој монаркији разлике племена, вире или политичког страначкога положаја кад се о томе ради, да се владару искаже штовање и почитање...само једна жеља напуњује срца свијух: Боже живи, штити и благослови љубљеног владара и пријасну царску и краљевску кућу“. ${ }^{32}$ Овакви текстови су имали вишеструку функцију. Сугерисали су читаоцу наводно јединство нација у Монархији када је у питању љубав и поштовање према владару, који је идеализовано описан као личност блиска сваком поједином „народу“, па сходно томе и појединцу. Осим тога, у другим текстовима, цар је приказиван као духовит човек, који на антисемитску шалу домишљато одговара да је он и јерусалимски краљ. ${ }^{33}$ Често је конструисан утисак о некој врсти блискости и везе владара и обичних људи из буњевачке и шокачке средине. Та метода посебно је дошла до изражаја у догађају са извесним редаром Томом који се прославио у служби „многим јуначким делима“ и хватањем разбојника, па је затражио да му због тога цар буде кум. Његова амбициозна идеја је награђена већим новчаним износом. ${ }^{34}$ Митологизација припадника династије добијала је највећи замах у кризним временима или трагичним случајевима. Приликом једног од атентата на Франца Јозефа, буњевачки аутор у Суботичкој Даници је захваљивао божијој промисли што цар није повређен, та „висока особа““ и „најбољи отац и најправеднији владар“. Пошто је „скупоцени живот“ цара сачуван, текст је пратила једна песма о владару и Буњевцима који га штите од свих опасности. ${ }^{35}$ Често су буњевачко-шокачки календари садржавали велике фотографије цара, престолонаследника Рудолфа, чланова царске породице, ${ }^{36}$ биографске податке о владару и врло детаљно приказану сложену генеалогију „прејасне владајушче и царске и краљевске аустријске куће“. ${ }^{37}$

Иако су разни текстови у буњевачким и шокачким новинама и календарима покушавали приближити династију обичном читаоцу и указати на доступност владара и његову повезаност, блискост и бригу за сваки народ у Монархији, ипак су поједини чланци потенцирали сасвим другачију тенденцију, што се може приписати карактеру „службеног национализма“ и његовој комбинаторици различитих и неспојивих идеологија и начела. Сакрализацијом је указивано на разлике између Хабзбурговаца и обичних грађана, јер припадници династије су „рођени на оној висини до којих не допиру бриге обичних људи и свакидашњег живота“. ${ }^{38}$ Таквом схватању су доприносили и поједини политичари својим поступцима. На затварању земаљске изложбе у Будимпешти 1885, када је царевић Рудолф завршио свој говор, министар Сечењи је „сузним очима и дрхћућом руком ухватио Њег. Висост за руку и пољубио је“. ${ }^{39}$ Сличну сврху стварања митске слике о династији имали су описи

\footnotetext{
${ }^{32}$ Neven, 15. rujna $1885,9$.

${ }^{33}$ Neven, 15 . sičnja 1885,1 .

${ }^{34}$ Neven, 15. studena $1885,11$.

${ }^{35}$ Subotička Danica: kalendar za 1892. godinu, Subotica 1891, 19-21.

${ }^{36}$ Subotička Danica: kalendar za 1890. godinu, Subotica 1889.

${ }^{37}$ Subotička Danica: kalendar za 1893. godinu, Subotica 1892; Subotička Danica: kalendar za 1894. godinu, Subotica 1893.

${ }^{38}$ Subotička Danica: kalendar za 1890. godinu, Subotica 1889, 46-48.

${ }^{39}$ Neven, 15. studena $1885,11$.
} 
одеће и богатства припадника династије у свечаним моментима или појединим јубилејима и прославама значајним за Монархију. Врло детаљно су описивани одела, хаљине украшене дијамантима, скупоцене кочије. Главна функција је била да се на тај начин династија митологизује. Међутим, вероватно је била присутна и жеља да се прикаже велика разлика између династије и обичних грађана, чиме је указивано да грађанска права, уставност, либерализам и национализам ипак не бришу разлике и не стварају друштво равноправних грађана. С једне стране, присутна је жеља да се династија приближи и повеже са грађанима, с друге стране на разне начине је указивано на разлику између сакрализоване династије и осталих делова друштва, као стално присутна напетост између непомирљивих идеолошких концепција.

Самоубиство царевића Рудолфа у Мајерлингу 1889. изазвало је праву ерупцију митологизације покојног царевог сина. У Суботичкој Даници појавио се текст који је говорио о „смрти опћељубљеног“ престолонаследника, која је „поразила све народе нашег узвишеног и племенитог краља““. Осим речи о великој и неограниченој љубави народа према Рудолфу, текст је био препун епитета о његовој личности, „племенитом срцу“ и „узвишеном уму“. Престолонаследник је био и добар војник, научник и књижевник, „хуман према свима“. Аутор чланка тврди да је имао све врлине које требају великом владару, „добро срце и оштар разум“, да је „моћни заштитник и добар отац“. Митска слика о Рудолфу допуњена је и наводном везом са Буњевцима. Према тексту чланка престолонаследник је знао све њихове тежње и жеље, „проучавао је наш народ и обичаје његове“, чак их је све волео и био им пријатељ, па је према томе био достојан наследник предака. Са очајањем аутор чланка закључује како је умрла „будућа звизда притходница липших дана монархије“. Показано је саучешће и за цара - „сви народи окупили се око сјајног пристола свога узвишеног старатеља, да по стардавној вирности“ поделе са њим несрећу, јер је он наводно увек делио радост и срећу са својим народима. У Даниии нису изнети готово никакви подаци о истрази у Мајерлингу, осим кратког податка да је Рудолф извршио самоубиство. ${ }^{40}$

Посебан део митологизације династије била је супруга Франца Јозефа, Елизабета, познатија као Сиси. Сиси је као интересантна личност била веома погодна за конструкције разних митских представа о Хабзбурговцима. Буњевачкошокачки листови су често пратили њена исто тако честа путовања и доносили извештаје о хуманитарним акцијама, царичиној доброти и хуманости. Царица је обилазила болеснике, падала на колена поред болесничких кревета и молила, док су болесници плакали када би видели њен наступ. Поклањала је и велике новчане износе здравственим заводима. ${ }^{41}$ Новине су такође преносиле вести како је Сиси радосно дочекивана у свим местима која је посећивала. ${ }^{42}$ Штампа је врло вешто уклапала интересантну царицу и њену везу са обичним људима у идеализовану слику о династији Хабзбург, иако је стварност њеног конфликтног односа са династијом у то време била сасвим другачија и мање позната јавности.

\footnotetext{
${ }^{40}$ Subotička Danica: kalendar za 1890. godinu, Subotica 1889, 46-9.

${ }^{41}$ Bunjevačke i šokačke novine, 20. travnja 1870, 6.

${ }^{42}$ Bunjevačke $i$ šokačke novine, 19. listopada 1870, 32.
} 
Митологизација династије је задржала многе елементе карактеристичне за средњи век. Идеја о светости династије и извесној разлици између грађана и Хабзбурговаца представљала је значајну тему у литератури и штампи, иако су чињени одређени кораци да се те разлике идеолошки умање. Суштина владарске филозофије Хабзбурговаца спречавала је да стари митови буду у потпуности замењени конструисањем нових традиција и митова, прикладнијих грађанском друштву. Сигурно је да већина митских конструкција није била прилагођена све бржим променама које је XIX век доносио, као ни довољна полуга у одржању власти над царством и нацијама, што је до пуног изражаја дошло 1918.

За Хабзбурговце је важан елемент у њиховој владарској идеологији био захтев „Kaisertreue“, односно верност цару. Од 1867, када је Угарска постала готово одвојена држава, „верност цару“ је остала начело легитимитета само у аустријском делу Монархије. ${ }^{43}$ Због тога, важно је напоменути да су припадници буњевачкошокачког националног покрета као своју домовину сматрали Угарску, док су Хабзбурговци представљани само као угарски краљеви овенчани круном Св. Стефана, из чега је између осталог, како смо видели, произлазио легитимитет њихове власти. Теза о верности домовини и владару сведена је на верност Угарској и њеном краљу.

Доказивање верности династији и домовини био је значајан сегмент у приказивању Хабзбурговаца у буњевачкој и шокачкој штампи. Њихови листови су садржавали безбројне тврдње о верности и оданости Буњеваца и Шокаца владару и угарској домовини. Аутори су писали да свако „матерински језик свој, домовину мајку своју и законито владарство безувитно љуби и поштује и до капи крви брани. Ту свету дужност нам и сама нарав налаже...Само дао Бог, да добре, вирне и побожне грађане одгојимо“. ${ }^{44}$ Већ од појављивања првих буњевачко-шокачких новина, аутори су писали о свим жртвама које су ове етничке заједнице поднеле за домовину. Сматрали су непријатељима све оне који би покушали угрозити круну Св. Стефана и територијални интегритет Угарске. На темељу те верности домовини и владару, захтевали су одређена политичка и грађанска права. ${ }^{45}$ Те захтеве су објашњавали „идејом суграђанства“, односно да могу постати искрене патриоте само ако се упознају са „новим идејама“ преко матерњег, буњевачког језика. ${ }^{46}$

Буњевачки и шокачки листови су често истицали заслуге предака у борби против Османлија. Наглашавали су како је њихова љубав према домовини неоспорна и да су се увек показали као цару и домовини верни борци, па су чак и царски генерали потврдили њихове заслуге. Пошто су истицали да је љубав према домовини Угарској нека врста наслеђа предака, повезивали су је са љубављу према матерњем буњевачком језику који су такође сматрали „вековним наслеђем“ и „народном светињом“. ${ }^{47}$ Како је митологизација добијала већи замах приликом кризних момената, тако су у тим случајевима и изјаве верности добијале нову

\footnotetext{
${ }^{43}$ H. S. Watson, Nacije i države, 152.

${ }^{44}$ Bunjevačke $i$ šokačke novine, 15 . travanj 1870, 4.

${ }^{45}$ Bunjevačke $i$ šokačke novine, 19 ožujak 1870, 1.

${ }^{46}$ Bunjevačke i šokačke novine, 30 ožujak 1870, 3.

${ }^{47}$ Subotička Danica: kalendar za 1890. godinu, Subotica 1889, 22-25.
} 
динамику, па су се у штампи често појављивале тезе о „најискренијој оданости“ и „поданичкој привржености““. 48

Посебно важна формулација у буњевачкој и шокачкој штампи, у контексту верности, представља теза о спремности жртвовања живота за домовину и краља. Буњевачки и шокачки аутори су прави патриотизам дефинисали као испуњавање дужности, просвећивање људи, али поистовећивали су га и са нужном употребом „народног буњевачког језика“. ${ }^{49}$ Према томе, одбрана земље од нападача и жртвовање је имало смисла, само ако њихова права буду реализована у оном обиму који су сматрали довољним. Жртвовање живота долазило је у обзир једино за одбрану уставне слободе и једнакости свих. Дакле, преко идеје о слободи појединца онако како је она дефинисана идеологијама национализма и либерализма, у читаоце новина је учитавана теза о потреби жртвовања уколико би та слобода била угрожена. ${ }^{50}$ Међутим, пошто већина нација у Монархији није сматрала да су сва та права остварена, сама идеја жртвовања за домовину, као и верност, постајале су не само бесмислене него и потенцијална опасност за опстанак Аустро-Угарске, како су уочавали поједини буњевачки и шокачки аутори још 1870. Ипак, све до пропасти Монархије, Буњевци и Шокци су се у својим листовима представљали као заједнице лојалне Угарској и њеном владару. Управо из те вековне лојалности произлазили су политички и просветни захтеви њиховог националног покрета.

Нема сумње да је идеја о политичком легитимитету власти у Монархији, када је реч о јужноугарским Буњевцима и Шокцима, доживела многе промене од 1790. до 1918. Промене у схватању извора власти и онога што политички легитимитет представља показују како је путем политичке модернизације изграђиван национални идентитет. Облици приказивања Хабзбурговаца у буњевачкој и шокачкој штампи током целог XIX века остали су у непосредној вези са круном Св. Стефана. Предводници националног покрета Буњеваца и Шокаца инсистирали су на тој вези, као лојални грађани Угарске. Међутим, за њихову лојалност, која је према оновременим новинама и литератури била вековна, тражена је награда у облику поштовања грађанских и политичких права. Буњевци и Шокци су у процесу модернизације прихватали нове грађанске идеологије и своју представу о политичком легитимитету власти су мењали, делимично је прилагођавајући националним и либералним схватањима, колико је то „службени национализам“ династије дозвољавао. Повезана са југословенском националном идејом, идеологија национализма међу Буњевцима и Шокцима резултирала је претварањем буњевачкошокачког покрета у масовни национални покрет 1918, који је одлучио да се припоји Краљевини СХС. Услед сложених процеса, изградња њиховог колективног идентитета у југословенској држави добила је нове облике и правце, у контексту хрватске и југословенске националне идеологије.

Колико год да је утицај двора, династије и цара низом конкретних поступака ограничавао идеју националног суверенитета у Монархији, ипак је кроз наведени

\footnotetext{
${ }^{48}$ Subotička Danica: kalendar za 1892. godinu, Subotica 1891.

${ }^{49}$ Bunjevačka i šokačka vila, 26. veljače $1874,5$.

${ }^{50}$ Bunjevačke $i$ šokačke novine, 30. studena 1871, 42.
} 
тип литературе и чланака у читаоце учитавана свест да владавина монарха проистиче из њихове воље и да је са њиховом вољом уско повезана. Док су у царевини владали унутрашњи мир и стабилност, а у Европи равнотежа снага, ширење либералних и националних идеја у периоду после Нагодбе нису биле посебно опасне за династију Хабзбург. Међутим, већина етничких заједница, укључујући Буњевце и Шокце, изградила је колективни иденитет који суштински није био везан за Хабзбурговце. У моменту пропасти њиховог царства, те заједнице су се отворено изјасниле о својој судбини, јер су идеолошки биле припремљене за идеју о националном самоопредељењу. „Службени национализам“ у случају АустроУгарске доживео је дефинитиван пораз 1918. Показало се да митске конструкције Хабзбурговаца нису могле задржати ни најлојалније заједнице у саставу Хабзбуршке царевине. Свакако у томе треба тражити један од разглога тако брзог распада Монархије.

Развој политичког легитимитета утемељеног на „народној вољи“ сигурно представља једну од кључних тема у проучавању политичких и друштвених односа у Монархији. Истраживање овог проблема у случају других етнија и нација свакако може допринети расветљавању многих процеса, као што су изградња националног идентитета; утицај идеологије национализма на поједине нације приликом стварања Југославије; и традиције политичке културе утемељене на „службеном национализму“, који је оставио дубок траг на све „народе“ династије Хабзбург.

\section{Извори и литература:}

Периодика и календари:

Bunjevačka i šokačka vila

Bunjevačke i šokačke novine

Neven

Subotička Danica

Литература:

Блед, Жан-Пол, Франи Јозеф, Београд 1998.

Велер, Ханс-Улрих, Национализам: историја, форме, последице, Нови Сад 2002.

Гавриловић, Славко, Сомбор у борби за елибертаичју: 1745-1749, Зборник Матице српске за историју, 37, Нови Сад 1988, 43-79.

Гелнер, Ернест, Нације и национализам, Нови Сад 1997.

Иванић, Иван, Буюевци и Шокци у Бачкој, Барањи и Лици, Београд 1899.

Ивић, Алекса, Из прошлости Буњеваща, О Буњевцима (зборник радова, ур. Кнежевић, Милоје), Суботица 1927, 12-17.

Кузмановић, Славко, О нащионалном препороду буњевачких Хрвата, Зборник за историју, 20, Нови Сад 1979, 131-159.

Никић, Федор, Буњевц̧и и Српска Војводина 1860, О Буњевцима (зборник радова, ур. Кнежевић, Милоје), Суботица 1927, 41-45. 
Никић, Федор, Румуни банатски и Буњевци према српској Војводини у год. 1848-1849, Летопис Матице српске, год. 101, књ. 313, св. 1-3, Нови Сад 1927, 406-415.

Радонић, Јован, О сеоби Буњеваиа у Суботииу 1687. године, сепарат, Београд 1954, 119-127.

Стајић, Васа, Мађаризаиија и демађаризаиија Буњеваиа, Летопис Матице српске, год. 104, књ. 325, св. 1-3, Нови Сад 1930, 158-209.

Тејлор, Ален Џ. П., Хабзбурика монархија: историја Аустријске иаревине и Аустроугарске, Београд 2001.

Anderson, Benedikt, Nacija: zamišljena zajednica, Beograd 1998.

Bačić, Slaven, Nacionalno-integracijski procesi Bunjevaca u Bačkoj i ugarskom Podunavlju, Godišnjak za znanstvena istraživanja Zavoda za kulturu vojvođanskih Hrvata, br. 2, Subotica 2010, 65-76.

Banac, Ivo, Nacionalno pitanje u Jugoslaviji: porijeklo, povijest, politika, Zagreb 1988.

Bašić-Palković, Nevenka, Grgur Peštalić: dostojna plemenite Bačke starih uspomena (1790), prvi rodoljubivi ep u književnosti bačkih Bunjevaca XVIII veka $i$ njegova izdanja, Etnolingvistička i istorijska istraživanja o Bunjevcima (zbornik radova, ur. Pižurica, Mato, Kujundžić-Ostojić, Suzana), Novi Sad - Subotica 2008, 49-59.

Cipek, Tihomir, Nacija kao izvor političkog legitimiteta, Nacija i nacionalizam u hrvatskoj povijesnoj tradiciji (zbornik radova, ur. Cipek, Tihomir, Vrandešić, Josip), Zagreb 2007, $17-33$.

Čović, Marko - Kokić, Aleksandar, Bunjevci i Šokci, Zagreb 1939.

Haselsteiner, Horst, Mađarski nacionalni koncepti, Slaveni i „Austro-slavizam“, u: Haselsteiner, Horst, Ogledi o modernizaciji, Zagreb 1997, 391-414.

Haselsteiner, Horst, O pojmu nacionalizma i njegovim strukturama u Jugoistočnoj Europi u 19. $i$ početkom 20. stoljeća, u: Haselsteiner, Horst, Ogledi o modernizaciji, Zagreb 1997, 289-325.

Haselsteiner, Horst, Problem narodnosti u zemljama ugarske krune, u: Haselsteiner, Horst, Ogledi o modernizaciji, Zagreb 1997, 326-351.

Hobsbaum, Erik, Nacije i nacionalizam od 1780: program, mit, stvarnost, Beograd 1996.

Hroch, Miroslav, Društveni preduvjeti nacionalnih preporoda u Europi - komparativna analiza društvenog sastava patriotskih grupa malih europskih nacija, Zagreb 2006.

Pekić, Petar, Povijest Hrvata u Vojvodini: od najstarijih vremena do 1929. godine, Zagreb 1930.

Peštalić, Grgur, Dostojna plemenite Bacske starih uspomena sadashnji $i$ drugi slavinske kervi delliah slava, Subotica 1866.

Sekulić, Ante, O društvenom i stranačkom životu podunavskih Hrvata od 1867. do 1918, Historijski zbornik, sv. 41, br. 1, Zagreb 1988, 123-183.

Skenderović, Robert, Oblikovanje bunjevačkog političkog identiteta u Bačkoj tijekom druge polovice XIX stoljeća, Časopis za suvremenu povijest, sv. 44, br. 1, Zagreb 2012, 137-160.

Skenderović, Robert, Suradnja biskupa J. J. Strossmayera i Ivana Antunovića, Croatica Christiana periodica, 59, Zagreb 2007, 85-103.

Smit, Antoni D., Nacionalni identitet, Beograd 1998.

Smith, Anthony D., Nacionalizam i modernizam: kritički pregled suvremenih teorija nacija $i$ nacionalizama, Zagreb 2003.

Stančić, Nikša, Između političkog nacionalizma i etnonacionalizma: od hrvatske staleške „nacije“ (natio croatica) do hrvatskog „političkog naroda“, Nacija i nacionalizam u hrvatskoj povijesnoj tradiciji (zbornik radova, ur. Cipek, Tihomir, Vrandešić, Josip), Zagreb 2007, $33-56$. 
Suppan, Arnold, Cuius regio eius natio: nacionalno razgraničavanje, isključivanje $i$ asimilacija $u$ srednjoistočnoj Europi, u: Suppan, Arnold, Oblikovanje nacije u građanskoj Hrvatskoj (1835-1918), Zagreb 1999, 21-36.

Watson-Seton, Hugh, Nacije i države: ispitivanje porijekla nacija i politike nacionalizma, Zagreb 1980.

Wheatcroft, Andrew, The Habsburgs, London 1995.

POLITICAL LEGITIMACY, MYTH, FIDELITY: THE HABSBURGS IN THE LITERATURE AND NEWSPAPERS OF BUNJEVCI AND ŠOKCI 1790-1918

\begin{abstract}
Summary
When south Hungarian Bunjevci and Šokci are in question, the idea of political legitimacy of sovereignty in Austro-Hungarian Monarchy experienced great changes in the period from 1790 to 1918 . The changes in the concept of the sources of sovereignty and political legitimacy both show how political modernization built national identity. No matter how great the influence of the Court, the dynasty or the Emperor was in the series of practical acts that constricted the idea of national sovereignty in the Monarchy, in their literature and newspapers Bunjevci and Šokci spread the awareness that monarch's rule derived from their will and that it was firmly connected to their will. Most of the ethnic communities, including Bunjevci and Šokci, built their collective identity with no essential connection to the Habsburgs. In the moment of the collapse of their empire, these communities made an open declaration on their fate, because they were ideologically prepared for the idea of national self-determination.
\end{abstract}

Keywords: Bunjevci, Šokci, Habsburg dynasty, southern Hungary, political legitimacy, myth, fidelity, national movements, collective identity. 